\title{
Kahkewistahaw First Nation v Taypotat - Whither Section 25 of the Charter?
}

\section{Jennifer Koshan and Jonnette Watson Hamilton*}

\section{Introduction}

The Supreme Court of Canada has to date delivered eight Charter equality decisions in an Aboriginal context. ${ }^{1}$ In the most recent case, Kahkewistahaw First Nation $v$ Taypotat, the Court unanimously dismissed Louis Taypotat's challenge to his community's election code requirement that members of the First Nation running for election as Chief or Band Councillor have a Grade 12 education or its equivalent.

Taypotat, aged 76, had previously held office as Chief for almost thirty years in total, but he was disqualified from running again in 2011 because he did not meet the new education requirement. He had attended residential school until he was fourteen, and his education had been subsequently assessed at a Grade 10 level. Before the Supreme Court, Taypotat argued that the community election code had an adverse impact on him on the basis of his age, residency on a reserve, and status as a residential school survivor. $^{2}$

In rejecting Taypotat's argument that the community election code was discriminatory, the Court focused on the objectives behind the First Nation's adoption of the education requirement. ${ }^{3}$ It cited the Report of the Royal Commission on Aboriginal Peoples to assert the idea that education is "a top priority for promoting collective and individual well-being in Aboriginal communities, and for helping those communities prepare to assume the complete range of responsibilities associated with self-government." 4 Seen in this light, the election code's education requirement might have been treated as a matter to be shielded from scrutiny under section 25 of the Charter, which requires Charter rights to be interpreted so as not to derogate from Aboriginal, treaty or other rights. However, the Kahkewistahaw First Nation did not make a section 25 argument before the Supreme Court. ${ }^{5}$

In fact, the Court has not dealt with section 25 since $R v$ Kapp in 2008, and then it was only the concurring judgment of Justice Bastarache that fully explored the implications of the section. ${ }^{6}$ Given this lack of guidance, it is not surprising that section 25 arguments are being omitted in Charter litigation.

We contend that the absence of a section 25 analysis in Taypotat was a missed opportunity, particularly because Taypotat is the only section 15(1) decision of the Supreme Court with an Aboriginal government as respondent. ${ }^{7}$ In the following part, we review the Court's approach to section 25 and the potential application of section 25 in Taypotat. We conclude with a plea to litigators and the courts to move section 25 jurisprudence forward.

\section{Section 25 of the Charter}

Taypotat and other section 15(1) cases that raise challenges in the Aboriginal context present unique considerations. Aboriginal peoples are 
constitutionally recognized under section 35, have concomitant collective interests, including group title to land and the right to self-government, ${ }^{8}$ and have been (and continue to be) subjected to the forces of colonization in ways that distinguish them from other groups under the Charter. ${ }^{9}$ Section 15(1) claims engaging the collective interests of Aboriginal peoples may be brought by Aboriginal or non-Aboriginal persons against Aboriginal or settler governments, and each combination of parties may give rise to different considerations. More critically, Charter claims in the Aboriginal context typically involve significant cultural differences between the parties and decision-makers, ${ }^{10}$ which raise profound questions about the role of the courts and their application of Euro-Canadian laws.

This complex historical and socio-political context is underscored in section 25 of the Charter, ${ }^{11}$ which provides that:

25 The guarantee in this Charter of certain rights and freedoms shall not be construed so as to abrogate or derogate from any aboriginal, treaty or other rights or freedoms that pertain to the aboriginal peoples of Canada including

(a) any rights or freedoms that have been recognized by the Royal Proclamation of October 7, 1763; and

(b) any rights or freedoms that now exist by way of land claims agreements or may be so acquired.

The first section 15(1) case in which section 25 was argued in the Supreme Court was Corbiere $v$ Canada, a challenge to voting restrictions on off-reserve band members under the Indian Act. ${ }^{12}$ An intervener, the Lesser Slave Lake Indian Regional Council, argued that section 25 should shield a First Nation's right to control its own membership (and by implication control who was entitled to live on the reserve).${ }^{13}$ A majority of the Court declined to apply the section, indicating that it "would be inappropriate to articulate general principles" on section 25 in light of the limited argument on the issue. ${ }^{14}$

The only Supreme Court decision in which section 25 has been dealt with at any length is
Kapp, a section 15(1) claim by largely nonAboriginal fishers against the government for granting priority fishing licenses to three First Nations. In his concurring opinion, Justice Bastarache referenced legislative history, academic and judicial commentary, and found that section 25 was intended to serve as a shield rather than simply as an interpretive provision, for the purpose of "protecting the rights of aboriginal peoples where the application of the Charter protections for individuals would diminish the distinctive, collective and cultural identity of an aboriginal group." ${ }^{15}$ He considered the scope of section 25, finding that the words "aboriginal, treaty or other rights or freedoms" should be interpreted broadly so as to protect "federal, provincial and Aboriginal initiatives that seek to further interests associated with indigenous difference from Charter scrutiny." 16 Justice Bastarache's approach to the application of section 25 involved three steps:

\begin{abstract}
The first step requires an evaluation of the claim in order to establish the nature of the substantive Charter right and whether the claim is made out, prima facie. The second step requires an evaluation of the native right to establish whether it falls under s. 25 . The third step requires a determination of the existence of a true conflict between the Charter right and the native right. ${ }^{17}$
\end{abstract}

Applying this test to the priority Aboriginal fishery challenged in Kapp, he disposed of the claim on the basis that, although there was a prima facie case of discrimination under section 15(1), the fishing rights at issue were protected by section 25 and the conflict between those rights triggered the shield in section $25 .{ }^{18}$

Justice Bastarache wrote only for himself in $K a p p$, and the majority raised some concerns about his approach. ${ }^{19}$ Chief Justice McLachlin and Justice Abella took a narrower view of the scope of section 25 , suggesting that "only rights of a constitutional character are likely to benefit" from the section..$^{20}$ They also questioned whether section 25 should operate as a shield rather than as an interpretive provision, indicating that "these issues raise complex questions of the utmost importance to the peaceful reconciliation of aboriginal entitlements with the interests of all 
Canadians ... . [and] are best left for resolution on a case-by-case basis as they arise before the Court." 21

Although section 25 was not argued by the Kahkewistahaw First Nation in Taypotat at the Supreme Court level, the Chief and Band Councillors did place great emphasis on the First Nation's collective adoption of the community election code. ${ }^{22}$ They noted that " $\left.\mathrm{t}\right]$ he provision of education and establishment of schools on reserve were conditions insisted upon by First Nations during the negotiations leading to the numbered treaties, including to Treaty 4 , to which the Kahkewistahaw First Nation became signatory in 1874." 23 However, they invoked section 15(2), the Charter's affirmative action provision, to shield the code from a finding of discrimination, rather than section $25 .^{24}$ In light of the Court's finding that there was insufficient evidence to support a distinction based on a protected ground, it did not deal with their section 15(2) argument. The use of section 15(2) instead of section 25 may be a result of a lack of guidance from the Court on the latter provision, including direction on when section 25 should be pled and the consequences of doing so might be.

In upholding Taypotat's discrimination claim, the Federal Court of Appeal found section 25 inapplicable because "no aboriginal, treaty or other rights have been raised in these proceedings as a bar to the appellant's challenge to the provisions of the Kahkewistahaw Election Act." 25 However, Gordon Christie has argued that community election rules could be seen as "aboriginal, treaty or other rights" under section $25 .{ }^{26}$ If this is so, should Justice Bastarache's approach to section 25 in Kapp, developed in the context of a section 15(1) challenge by non-members, apply in the same way to exercises of self-government by a First Nation to which one of its members brings the challenge. ${ }^{27}$ In his pre-Kapp analysis of section 25, Christie argued that while the section should create a "strong hedge" around aboriginal, treaty and other rights in challenges brought by non-members, "in the absence of viable community-based alternative governing structures grounded in traditional principles and values, it would not protect Aboriginal governments from member-initiated challenges based on Charter principles." ${ }^{28} \mathrm{He}$ was of the view that these types of challenges were necessary in order to break down colonial power structures imposed on Aboriginal communities. ${ }^{29}$ The application of section 25 may therefore differ depending on who brings the claim against whom and when.

On this point, the Federal Court of Appeal in Taypotat indicated that the education requirement improperly incorporated a Euro-Canadian model, calling into question the suitability of the requirement and the applicability of section 25. ${ }^{30}$ In response, the Chief and Councillors argued that the Court of Appeal showed "EuroCanadian bias" in this aspect of their reasoning, noting that the Kahkewistahaw First Nation took education and the establishment of schools seriously at the time of treaty negotiations and has since expended considerable resources on education in the community. ${ }^{31}$ They also argued that the Court of Appeal's view was based on "the premise that only 'Euro-Canadians' value education, when the history and facts relating to First Nations in general, and this First Nation in particular, demonstrate otherwise." ${ }^{32}$ These arguments underscore the complexity of the socio-political, historical and factual contexts in Taypotat, and the importance of considering the application of section 25 in section 15(1) challenges in the Aboriginal context.

\section{Conclusion}

The Supreme Court in Taypotat appeared reluctant to burden the Kahkewistahaw First Nation with justification of its education requirement. However, as we have argued elsewhere, this reluctance was manifested in an approach to section 15(1) of the Charter that emphasized the lack of arbitrariness of the education requirement, thereby muddying the Court's definition of discrimination. Here we are contending that the more appropriate place for the Court to have considered community goals was under section 25 of the Charter, or alternatively under section $1 .^{33}$

We do not suggest that section 15(1) has no role to play for Aboriginal claimants, even 
when they challenge their communities' laws. For example, the claim by the Native Women's Association of Canada for an equal role in debating constitutional reforms (including whether the Charter should apply to Aboriginal governments), ${ }^{34}$ the Sawridge litigation concerning band membership rules that exclude some Bill C-31 women and their children, ${ }^{35}$ and the allegation that election codes in some Aboriginal communities may prevent individuals from running for office on the basis of their gender, marital status or sexual orientation, ${ }^{36}$ all raise important issues about the construction of and balance between individual and collective interests. ${ }^{37} \mathrm{In}$ the context of claims by Aboriginal women, it also must be recognized that gender equality is protected in both section 28 of the Charter and section 35(4) of the Constitution Act, 1982, using language that may override section $25 .{ }^{38}$

We urge the courts to develop an approach to these issues that recognizes RCAP's admonition that, under section 25, "the Charter must be given a flexible interpretation that takes account of the distinctive philosophies, traditions and cultural practices of Aboriginal peoples." ${ }^{39}$ And we urge litigators not to give up on making section 25 arguments.

\section{Endnotes}

* Professors, Faculty of Law, University of Calgary.

1 Native Women's Association of Canada v Canada, [1994] 3 SCR 627 [NWAC] (government funding for Aboriginal women's group seeks government funding to allow participation in constitutional talks); Corbiere v Canada, [1999] 2 SCR 203 [Corbiere] (voting restrictions on off-reserve band members); Lovelace v Ontario, 2000 SCC 37, [2000] 1 SCR 950 (distribution of reserve-based casino proceeds to Indian bands only); $R v$ Kapp, 2008 SCC 41, [2008] 2 SCR 483 [Kapp] (priority to holders of Aboriginal fishing licences); Ermineskin Indian Band and Nation v Canada, 2009 SCC 9, [2009] 1 SCR 222 (Crown management of oil and gas revenues for an Indian band); Alberta (Aboriginal Affairs and Northern Development) v Cunningham, 2011 SCC 37, [2011] 2 SCR 670 [Cunningham] (Métis Settlement membership rules); $R v$ Kokopenace, [2015] 2 SCR 398, 2015 SCC
28 (jury representativeness); and Kahkewistahaw First Nation $v$ Taypotat, [2015] 2 SCR 548, 2015 SCC 30 [Taypotat] (community election code). For a discussion of equality claims involving Aboriginal status, see Ian Peach, "Section 15 of the Canadian Charter of Rights and Freedoms of the Future of Federal Regulation of Indian Status" (2012) 45 UBCL Rev 103.

2 Taypotat, supra note 1 at paras 4-14.

3 For an analysis of the Court's section 15 reasons in Taypotat, see Jonnette Watson Hamilton \& Jennifer Koshan, "Kahkewistahaw First Nation v Taypotat: An Arbitrary Approach to Discrimination" (forthcoming, SCLR).

4 Taypotat, supra note 1 at para 1, citing Report of the Royal Commission on Aboriginal Peoples, vol 3, Gathering Strength (1996) at 433, 540-41 [RCAP Report].

5 The Federal Court of Appeal did refer to section 25; see Taypotat $v$ Taypotat, 2013 FCA 192 at paras 41-42 [Taypotat FCA] and the discussion in the text accompanying note 25 .

6 Kapp, supra note 1 at para 76.

7 The Federal Court of Appeal found that the Charter applied to the Kahkewistahaw First Nation and its election code. See Taypotat FCA, supra note 5 at paras 36-42. This finding was not challenged on appeal.

8 See e.g. Tsilhqot'in Nation v British Columbia, 2014 SCC 44, [2014] 2 SCR 257 (the Supreme Court's most recent case on Aboriginal title); United Nations Declaration on the Rights of Indigenous Peoples, A/RES/54/263 (2000), art 1 (guaranteeing the right of self-determination).

9 See e.g. D’Arcy Vermette, “Dizzying Dialogue: Canadian Courts and the Continuing Justification of the Dispossession of Aboriginal Peoples" (2011) 29:1 Windsor YB Access Just 55.

10 See e.g. Gordon Christie, "Aboriginal Citizenship: Sections 35, 25 and 15 of Canada's Constitution Act, 1982" (2003) 7:4 Citizenship Studies 481 at 482.

11 See e.g. Christie, ibid at 488-93; Peter Hogg \& MaryEllen Turpel, "Implementing Aboriginal SelfGovernment: Constitutional and Jurisdictional Issues" (1995) 74:2 Can Bar Rev 187 at 214-15; Kent McNeil, "Aboriginal Governments and the Canadian Charter of Rights and Freedoms" (1996) 34:1 Osgoode Hall LJ 61 at 73-79; and the literature cited in Kapp, supra note 1.

12 Indian Act, RSC 1985, c I-5.

13 See Christie, supra note 10 at 489.

14 Corbiere, supra note 1 at para 20. In her concurring judgment, Justice L'Heureux Dubé made some 
general comments about section 25, but declined to apply it for the same reasons (ibid at paras 5154).

15 Kapp, supra note 1 at para 89, citing Jane M. Arbour, "The Protection of Aboriginal Rights Within a Human Rights Regime: In Search of an Analytical Framework for Section 25 of the Canadian Charter of Rights and Freedoms" (2003), 21 SCLR (2d) 3 at 60.

16 Kapp, supra note 1 at para 103 [emphasis added], quoting Patrick Macklem, Indigenous Difference and the Constitution of Canada (Toronto: University of Toronto Press, 2001) at 255.

17 Kapp, supra note 1 at para 111.

$18 \mathrm{Ibid}$ at paras 112-23. For a critique of the finding of prima facie discrimination based on race in Kapp, see e.g. Constance MacIntosh, "Developments in Aboriginal Law: The 2008-9 Term" (2008) 49 SCLR (2d) 1 at 16-17; June McCue, "Kapp's Distinctions: Race-Based Fisheries, the Limits of Affirmative Action for Aboriginal Peoples and Skirting Aboriginal People's Unique Constitutional Status Once Again” (2008) 5 Directions 56; Sébastien Grammond, "Disentangling 'Race' and Indigenous Status: The Role of Ethnicity" (2008) 33 Queen's LJ 487.

19 For critiques of the Kapp majority for failing to fully engage with section 25 , see e.g. Sophia Moreau, " $R$. v. Kapp: New Directions for Section 15” (2008-2009) 40:2 Ottawa L Rev 283 at 29798; Dominique Nouvet, "R. v. Kapp: A Case of Unfulfilled Potential” (2010) 8:1 Indigenous LJ 81 at 91-93.

20 Kapp, supra note 1 at para 63.

$21 \mathrm{Ibid}$ at para 65.

22 Factum of the Appellants Chief Sheldon Taypotat, Michael Bob, Janice Mckay, Iris Taypotat and Vera Wasacase as Chief and Council Representatives of the Kahkewistahaw First Nation, online at para 4: Supreme Court of Canada, <www.scc-csc.ca/ WebDocuments-DocumentsWeb/35518/FM010_ Appellant_Chief-Sheldon-Taypotat-et-al.pdf> [Factum of the Appellants].

23 Ibid at para 91. The election code at issue in Taypotat was not a traditional election law; it was based on delegated powers under the Indian Act, supra note 12. See Taypotat, supra note 1 at para 3.

24 Factum of the Appellants, supra note 22 at paras 102-16. Since Kapp, supra note 1, section 15(2) has been treated as a shield for claims of discrimination where the government can establish that it is protecting an ameliorative program. See also Cunningham, supra note 1, which extended Kapp to protect underinclusive ameliorative programs from section 15(1) scrutiny. For analysis of section 15(2) and the significance of the Aboriginal context of Kapp and Cunningham to the Supreme Court's approach to that section, see Jonnette Watson Hamilton \& Jennifer Koshan, "The Supreme Court, Ameliorative Programs, and Disability: Not Getting It" (2013) 25 CJWL 56 at 69-71. See also Peach, supra note 1 at 121-22 (critiquing Cunningham's approach to underinclusive ameliorative programs in this context).

25 Taypotat FCA, supra note 5 at para 42.

26 Christie, supra note 10 at 485-87.

27 Justice Bastarache did say, in obiter, that "It is not at all obvious in my view that it is necessary to constrain the individual rights of Aboriginals in order to recognize collective rights under s. 25.": Kapp, supra note 1 at para 99.

28 Christie, supra note 10 at 491 . See also McNeil, supra note 11 at 74 , who argues that section 25 must apply to exercises of power by First Nations' governments over their own people so as to give adequate meaning to the word "derogate" in section 25. As noted by Patricia Hughes, this issue was not resolved in Kapp. See "Resiling from Reconciling? Musing on R v Kapp" (2009) 47 SCLR (2d) 255 at 279.

29 Christie, supra note 10 at 491.

30 Taypotat FCA, supra note 5 at para 59.

31 Factum of the Appellants, supra note 22 at para 91.

$32 \mathrm{Ibid}$ at para 92.

33 Section 15(2) may also be an appropriate place to consider community goals where a targeted ameliorative program is challenged. See Cunningham, supra note 1 . While section 15(2) was argued in Taypotat, it is difficult to see the education requirement as a targeted ameliorative program.

34 NWAC, supra note 1.

35 See Kirsty Gover, "When Tribalism Meets Liberalism: Human Rights and Indigenous Boundary Problems in Canada" (2014) 64:2 UTLJ 206; see also Stoney v Sawridge First Nation, 2013 FC 509, 2013 CarswellNat 1434.

36 Karen Busby, "Discussed, reformulated and enriched many times': The Supreme Court of Canada's Equality Jurisprudence" (Presentation delivered at the Canadian Bar Association Annual National Constitutional and Human Rights Conference, 9 July 2014) at 4-5, online: SSRN, $<$ www.ssrn.com/abstract $=2547671>$.

37 The individual / collective dichotomy may be inappropriate here, as Aboriginal women are often seeking equal access to collective rights. See Mary Eberts, Sharon McIvor \& Teressa Nahanee, 
"Native Women's Association of Canada v Canada" (2006) 18:1 CJWL 67 (a Women's Court of Canada "judgment" in NWAC, supra note 1).

38 McNeil, supra note 11 at 76-78; Kapp, supra note 1 at para 97.

39 RCAP Report, supra note 4, vol 2, Recommendation 17 at 231-32. 